\title{
A Maioria Perseguida: religião, ciência e democracia na audiência pública sobre aborto no STF
}

\author{
Mariana Azevedo ${ }^{a}$ \\ Roberto Efrem Filho ${ }^{\mathrm{b}}$
}

Resumo: $\bigcirc$ presente artigo busca contribuir para a compreensão das atuais configurações da religião na controvérsia pública sobre a descriminalização do aborto no Brasil. Para tanto, volta-se à análise da audiência pública realizada no Supremo Tribunal Federal como parte do processamento da ADPF 442, mas sobretudo às 24 exposições realizadas por representantes de entidades autodenominadas religiosas e pelos demais expositores que citaram a religião para a construção de seus argumentos contrários ou favoráveis à descriminalização do aborto até a $12^{\text {a }}$ semana de gestação. Tais exposições oportunizam intensas disputas - interiores a uma linguagem de direitos - em torno do conhecimento científico, de diferentes concepções de democracia e da própria religião. Nessas disputas, atores religiosos não raro se identificam como uma maioria perseguida pelos 'excessos ideológicos' característicos de um 'ativismo judicial' protagonizado pelos ministros do STF e contrário ao que seria a 'moral do povo' brasileiro.

Palavras-chave: Aborto, Religião, Ciência, Democracia, STF.

Tendo em vista o debate contemporâneo sobre a relevância de moralidades e agentes religiosos no cenário político nacional, o presente artigo busca contribuir para a compreensão das atuais configura-

a Doutoranda em Ciências Sociais (Unicamp). Mestra em Sociologia e graduada em Ciências Sociais (UFPE). Email: marianaazevedo2@gmail.com.

b Professor do Departamento de Ciências Jurídicas (UFPB) e do Programa de PósGraduação em Antropologia (UFPE). Email: robertoefremfilho@gmail.com. 
ções da religião na controvérsia pública sobre a descriminalização do aborto no Brasil. Para tanto, volta-se às manifestações que mencionaram a religião durante a audiência pública realizada no Supremo Tribunal Federal, nos dias 03 e 06 de agosto de 2018, como parte do processamento da Arguição de Descumprimento de Preceito Fundamental (ADPF) 442, ação esta ajuizada pelo Partido Socialismo e Liberdade (PSOL) em intenso diálogo com agentes do movimento feminista e, em especial, da Anis - Instituto de Bioética ${ }^{1}$. Protocolada em 08 de março de 2017, a ADPF 442 visa ao reconhecimento de que a criminalização do aborto até a $12^{\text {a }}$ semana de gestação, decorrente dos artigos 124 e 126 do Código Penal², contraria preceitos constitucionais.

Apesar de o aborto ser crime previsto no Código Penal desde 1940, as diversas iniciativas legislativas a seu respeito, com vistas a sua descriminalização ou ao seu enrijecimento punitivo, o insistente protagonismo da questão do aborto nos pleitos eleitorais nacionais, sua potência para a mobilização pública de pânicos morais por atores políticos conservadores, bem como a pujante e permanente atuação dos movimentos feministas pela legalização do aborto demonstram ser este um tema nada pacífico no debate público brasileiro.

No Legislativo, por exemplo, multiplicaram-se nos últimos anos projetos de lei que buscam restringir as possibilidades de acesso ao aborto legal, assim como surgiram Frentes Parlamentares ${ }^{3}$ (Miguel, Biroli \& Mariano 2017) que mantêm como seu principal objetivo a 'defesa da vida e da família', expressão esta que acabou por constituirse como uma forte antinomia a qualquer iniciativa de promoção e proteção dos direitos sexuais e reprodutivos (Leite 2019). Não à toa, as movimentações ocorridas em 2015 contra o Projeto de Lei 5069 de autoria do então deputado federal Eduardo Cunha (PMDB), quem intencionava dificultar o acesso ao aborto legal em casos de estupro - são apontadas como um dos momentos-chave para o que se vem chamando de a 'primavera feminista', momento no qual manifestações feministas mediadas pela web ocuparam massivamente as ruas de 
diversas cidades do país (Piscitelli 2017). Tais movimentações convergiram para a 'queda' de Eduardo Cunha e se fizeram sentir também nas últimas eleições presidenciais com o \#EleNão.

Em verdade, os próprios ministros do Supremo Tribunal Federal já se viram às voltas com a discussão sobre o aborto em diferentes oportunidades. Em novembro de 2016, os ministros da primeira turma da Corte, ao julgarem o Habeas Corpus 124306, afastaram a prisão preventiva de dois réus denunciados pelo cometimento do crime de aborto com consentimento da gestante. Em seu voto, o ministro Luís Roberto Barroso argumentou, dentre outras questões, que a criminalização do aborto é incompatível com os direitos sexuais e reprodutivos, a autonomia da mulher, a integridade física e psíquica da gestante e o princípio da igualdade (STF 2016). Entretanto, bastante antes do julgamento do HC 124306, a controvérsia do aborto já trespassara as discussões sobre as pesquisas com células-tronco embrionárias e sobre a interrupção voluntária da gestação de fetos anencefálicos, a propósito da ADI 3510 e da ADPF 54 respectivamente.

A Ação Declaratória de Inconstitucionalidade 3510 foi ajuizada em 2005 pelo então Procurador-Geral da República Claudio Fonteles contra o art. $5^{\circ}$ da Lei de Biossegurança, intencionando assim impedir o desenvolvimento de pesquisas com células-tronco. Por sua vez, a ADPF 54 foi movida em 2004 pela Confederação Nacional dos Trabalhadores na Saúde (CNTS) e resultou, tal qual ocorreria com a ADPF 442 anos depois, da intensa mobilização de agentes feministas, sobretudo a Anis - Instituto de Bioética, ensejando aquilo que Alba Ruibal viria a compreender como "uma inovação no repertório da ação coletiva dos movimentos pelos direitos sexuais e reprodutivos no Brasil, ao incorporar a judicialização perante o STF como parte de suas estratégias" (Ruibal 2020:1168). . Os ministros do Supremo julgaram a ADI 3510 em 2008 e a ADPF 54 em 2012, ratificando as constitucionalidades das pesquisas com células-tronco embrionárias e da interrupção voluntária da gestação de fetos anencefálicos. Apesar de os debates em torno da ADI 3510 não se haverem remetido expli- 
citamente ao aborto e de, no caso da ADPF 54, a estratégia discursiva das(os) defensoras(es) da descriminalização e a própria decisão final dos ministros se pautarem no termo 'antecipação terapêutica do parto', em contraposição à noção de 'aborto', ambas as questões tocam diretamente no sensível debate sobre o início da vida, pedra de toque da controvérsia pública sobre a legalização do aborto no Brasil (Luna 2018).

A noção de 'controvérsia' tem adquirido relevância nos debates contemporâneos sobre religião e espaço público, haja vista possibilitar a observação das atuações de diferentes agentes em disputa acerca de questão sobre a qual não há um consenso para a vida comum (Montero 2012; Sales 2015). Segundo Paula Montero (2012), as controvérsias estão diretamente relacionadas à questão da legitimidade, pois trazem a primeiro plano os conflitos sobre quais formas são consideradas legítimas para a formulação de um problema e sua resolução na esfera pública. Nesse sentido, no presente artigo, voltar-nos-emos apenas a uma parte da atual controvérsia sobre aborto, mais especificamente àquela que tangencia seu engendramento com a religião.

Com isso em mente e na tentativa de tematizar as possíveis configurações da religião no atual estado da controvérsia acerca da descriminalização do aborto, nós nos voltamos analiticamente neste texto às exposições realizadas, na audiência pública, pelos(as) representantes de entidades autodenominadas religiosas e pelos demais expositores que citaram a religião para a construção de seus argumentos contrários ou favoráveis à descriminalização do aborto até a $12^{\text {a }}$ semana de gestação. Temos assim um total de 24 exposições que, de alguma forma, referiram-se à religião durante a audiência pública.

A audiência pública sobre o aborto parece-nos consistir num instante privilegiado para a apreensão das atuações de agentes religiosos e seculares acerca da religião no espaço público porque em audiências assim diferentes sujeitos necessitam publicizar seus argumentos a fim de torná-los inteligíveis e legítimos frente à Corte e a seus ministros, mas igualmente perante uma ampla audiência, composta por distin- 
tos setores sociais ${ }^{5}$. Além disso, uma audiência pública desta natureza promove, diria Silvia Aguião (2017), o contato com um conjunto de esforços políticos direcionados a uma 'projeção de Estado' tomado como democrático, inclusivo e acolhedor de diferenças. Como exposto pela ministra Cármen Lúcia durante a abertura da audiência pública, "é para ouvir, entender todos os entendimentos sobre esse tema, que essa audiência pública, a 23a realizada por este STF, é espaço de acolhimento de todas as posições, de exame de todos os argumentos e fundamentos aqui trazidos, pelo que eu agradeço”.

Esta forma de projetar Estado requer o acordo mínimo de que a pluralidade importa, de maneira que atores os mais diversos, inclusive aqueles expressamente religiosos, devem ser escutados no processamento de uma ação judicial no Supremo Tribunal Federal. Como se vê, a elástica noção de pluralidade aí presente remete a certa compreensão da laicidade que, ao invés de recusar a participação de agentes religiosos na arena pública, percebe a dinâmica pluralista e concorrencial do campo religioso como garantidora da laicidade. Tal compreensão da laicidade enquanto pluralidade atrela-se no Brasil ao processo de expansão pentecostal e à sua incisiva crítica à hegemonia católica, como Ricardo Mariano (2011) já notou.

A audiência pública realizada em 03 e 06 de agosto de 2018 foi convocada e conduzida pela ministra Rosa Weber, relatora da ADPF 442, e contou com expositores(as) de entidades médicas, científicas, jurídicas, feministas, religiosas e/ou que se autoidentificam como de 'defesa da vida' ${ }^{\text {. No }}$ que tange à posição dos(as) expositores(as), não houve uma distribuição equânime entre opiniões contrárias e favoráveis à adoção dos pedidos da ADPF 442, ou mesmo em relação à origem institucional. Ao assistir à gravação da audiência que está disponível no canal do Supremo Tribunal Federal no Youtube, contabilizamos 33 posições favoráveis à adoção dos pedidos da ADPF e 15 contrárias. Esta significativa diferença foi notada e denunciada por parte dos(as) expositores(as) que acusaram o STF de ativismo judicial. 
No tocante às representações religiosas, 13 das 50 exposições programadas eram de entidades religiosas, das quais 10 efetivamente ocorreram devido à ausência de representantes da Sociedade Budista do Brasil e da Federação Nacional do Culto Afro-Brasileiro (FENACAB). Foram ouvidos representantes da Confederação dos Bispos do Brasil (CNBB), da Associação dos Juristas Evangélicos (ANAJURE), do Conselho do Laicato no Brasil na Arquidiocese de Aracaju (CONAL), da Convenção Geral das Assembleias de Deus, da Convenção Batista Brasileira, do Instituto de Estudos da Religião (ISER) ${ }^{7}$, da Federação Espírita Brasileira, da União dos Juristas Católicos de São Paulo (UJUCASP), das Católicas Pelo Direito de Decidir, da Confederação Israelita do Brasil e da Federação das Associações Muçulmanas do Brasil (FAMBRAS).

Em que pese a atuação sistemática de agentes religiosos contra as possibilidades de ampliação do acesso ao aborto, este grupo não se trata de um bloco monolítico, contemplando também posições a favor da adoção dos pedidos da ADPF 442. Este é o caso, por exemplo, das Católicas Pelo Direito de Decidir e da Confederação Israelita do Brasil. No caso das Católicas, sua posição expressa não apenas a diversidade de posições no campo religioso, mas expõe também as fraturas e disputas internas ao próprio catolicismo (Oliveira 2009; Serra 2019; Rosado-Nunes 2012). Podemos lembrar ainda que, apesar de 'os evangélicos' serem comumente antagonizados como um bloco unitário contrário a qualquer pauta favorável a direitos sexuais e reprodutivos, o Bispo Edir Macedo, liderança proeminente da Igreja Universal do Reino de Deus, já se manifestou publicamente, em diversas ocasiões, a favor da legalização do aborto (Machado 2000; Gomes 2009).

\section{Religião e espaço público}

As diferentes configurações das religiões no espaço público têm sido objeto de preocupação de pesquisadoras(es) e de uma diversidade de atores políticos. Tais preocupações teóricas e políticas estão informadas em grande medida pela hegemonia do suposto weberiano da 
secularização, que compreende a modernização como sinônimo de privatização das religiões. Mais que apontar uma tendência observada, a secularização se tornou um verdadeiro postulado, um caminho teleológico a ser percorrido por todas as sociedades que se pretendiam ou se pretendem modernas, colocando a religião como um obstáculo à democracia (Montero 2006; Casanova 1992). Contemporaneamente, é senso comum a ideia de que sociedades modernas são aquelas que, dentre outras características, possuem uma clara separação entre religião e Estado. Como aponta Said (2007), a própria autoimagem do ocidente moderno se constituiu em contraposição à produção de um certo oriente atrasado porque dominado por paixões religiosas.

Diversos autores têm assinalado, contudo, a insuficiência e os problemas teóricos decorrentes do predomínio do paradigma da secularização (Casanova 1992; Montero 2009a; Vaggione 2012). A noção de desprivatização formulada por José Casanova (1992) aponta para a tendência segundo a qual, ao invés de se privatizarem, as religiões têmse feito presente das mais diversas maneiras no espaço público. Durante o Concílio Vaticano II (1962-1965), a Igreja Católica renuncia à pretensão de igreja universal e assume a defesa da liberdade religiosa, o que não significa abrir mão de sua participação nas questões públicas. Neste momento, o que se observa é uma mudança de estratégia segundo a qual agentes da Igreja passam a atuar como parte integrante de sociedade civil (Casanova 2010; Vaggione 2012).

Casanova (2010) observa como, por exemplo, diante de um contexto de globalização, a atuação de Papas como João XXIII e João Paulo II - com suas viagens ao redor do mundo e a publicação de Encíclicas Papais cada vez mais voltadas ao mundo secular, e não apenas à comunidade católica - busca construir a imagem pública do Papa como o "primeiro cidadão de uma sociedade civil global" (Casanova 2010:36). Vaggione (2012), por sua vez, ao se debruçar sobre os deslocamentos estratégicos da Igreja Católica frente ao avanço da agenda dos direitos sexuais e reprodutivos, identifica o que chama de 'onguização’ do ativismo católico, ocorrida a partir da década de 1970, 
com a criação, especialmente nos Estados Unidos, de diversas ONGs 'pró-vida' e 'pró-família'.

No caso brasileiro, é amplamente conhecido o importante papel que agentes da Igreja Católica desempenharam no enfrentamento à ditadura militar e nas lutas pelos direitos sociais e contra a carestia nas décadas de 1960 e 1970. Para além disso, como Paula Montero (2009a, 2012) bem demonstrou, o catolicismo forjou nossa linguagem política e as formas consideradas legítimas de reivindicação de direitos, sendo, por exemplo, as ideias de ação social e assistência social tributárias da virtude religiosa da caridade. As Comunidades Eclesiais de Base, tão fundamentais para a resistência popular durante o período ditatorial, formaram, nas palavras da autora, verdadeira "síntese entre comunidade de culto e comunidade política" (Montero 2009a:16), compondo em grande medida nossos ideais de participação e aliança política. É assim que Montero chama atenção para a existência de uma desigualdade estrutural e histórica nas formas de percepção da atuação legítima das diferentes religiões no espaço público brasileiro, no qual o catolicismo ainda conserva sua primazia, ainda que desafiada pioneiramente pelo protestantismo pentecostal (Montero 2012).

O aumento de canais de rádio e televisão ligados às igrejas evangélicas e o já mencionado número crescente de frentes parlamentares autodenominadas evangélicas são as expressões mais óbvias de que as religiões, especialmente as cristãs, têm atuado no Brasil como 'religiões públicas' - ou seja, aquelas que assumem ou tentam assumir um caráter, uma função ou um papel público (Casanova 1992). A notável incidência do catolicismo na constituição do espaço público e a expansão de agentes e práticas religiosas nesse espaço demonstram, como percebeu Paula Montero (2009a), que a categoria secularização adstringe-se à esfera normativa. Esta conclusão permite a Montero o exercício analítico, que nós buscamos aqui acompanhar, de buscar observar como cada processo histórico particular produz diferentes configurações acerca da presença da religião no espaço público. 
Com efeito, uma questão contemporânea premente diz respeito a sobre como, em sociedades orientadas pelo princípio da laicidade, diferentes religiões têm recorrido a linguagens e traduções seculares com vistas à atuação na esfera pública. Isto se nota no recurso à ciência nos debates sobre descriminalização do aborto, como veremos, mas também nas contendas acerca da origem da homossexualidade e da sua possivel cura mediante tratamento psicológico. Nessas contendas, segundo Alexandre Oviedo Gonçalves (2019), o próprio campo da psicologia, seu conselho federal e suas normatizações - sobretudo a Resolução 01/99, a qual proíbe que psicólogos brasileiros se envolvam com eventos e serviços que ofertem a referida cura - têm sua autoridade e suas competências contestadas e disputadas.

A noção de tradução tem origem na teoria habermasiana, mais precisamente na sua reformulação dos marcos normativos que até então negavam a possibilidade de participação da religião na esfera pública democrática (Habermas 2006). Ao formular a noção de póssecular, Habermas intencionou repensar os limites entre religião e democracia, mas não mais baseando-se no secularismo. Dessa forma, admite que os indivíduos possam manifestar-se na arena pública a partir de razões religiosas. Entretanto, sendo a arena pública espaço de produção de consensos, seria necessário que tais razões passassem por um filtro secular a fim de obter legitimidade (Habermas 2006; Vaggione 2012; Montero 2009b).

Mesmo concordando com as já amplamente conhecidas críticas - inclusive feministas, como as de Nancy Fraser (1995) - à teoria do agir comunicativo, que deixa de considerar as formas como as desigualdades atuam nas (im)possibilidades de reconhecimento e atuação na esfera pública, parece-nos que a noção de 'tradução', derivada do investimento habermasiano na noção de 'pós-secular', revela-se produtiva para o exercício analítico aqui proposto, visto que enseja conjeturar as estratégias de publicização de agentes religiosos em meio à controvérsia pública sobre a descriminalização do aborto no Brasil. 
A convocação de 13 entidades identificadas como religiosas para compor o grupo de 'especialistas' presentes na audiência denota o papel relevante que as religiões gozam na arena pública brasileira no que tange ao debate acerca da descriminalização do aborto. Apesar de a ministra Cármen Lúcia, então presidente do Supremo, abrir os trabalhos da audiência pública afirmando que 'o tribunal' analisará o problema sob ponto de vista exclusivamente jurídico, ela própria assinala que este é um tema que mobiliza não apenas a racionalidade, mas que toca:

[...] valores sob os quais se vive em sociedade, mas de maneira muito especial, a conceitos que vêm de longa data. E que sedimentaram entendimentos culturais e práticas que acabam levando não apenas ao exame de conceitos, mas na sociedade, a sentimentos que muitas vezes levam a, não vou dizer, incompreensões, mas pelo menos, a tendências muito diferentes [...].

A ministra Rosa Weber, por sua vez, afirma tratar-se "de tema jurídico delicado, sensivel, altamente polêmico, enquanto envolve razões de ordem ética, moral e religiosa. E que provoca muitas vezes reações extremadas". Mesmo enfatizando o caráter jurídico do problema, as ministras não deixaram de reconhecer o importante papel das religiões e moralidades na conformação dos valores que balizam questão tão polêmica, tanto que, como dito, convocaram representantes de diferentes religiões para expressarem suas visões sobre o aborto e ressaltaram que o STF está aberto a todas as compreensões, ainda que, diante de divergências, decisões devam ser tomadas.

A forte presença de representantes de organizações religiosas na audiência pública é fiadora de sua legitimidade e, portanto, daquela projeção de Estado como democrático, inclusivo e acolhedor de diferenças. Ao que parece, a ausência desses(as) representantes oporia obstáculos à figuração da audiência como uma instância estatal legítima e adequada para fazer conhecer os diferentes 'entendimentos' e 'sentimentos' acerca da controvérsia do aborto. Sendo assim, além de uma resposta à necessidade de considerar certa pluralidade, essa forte 
presença de agentes religiosos numa audiência pública no Supremo Tribunal Federal expõe, mais amplamente, o alto grau de relevância desses agentes no espaço público e nos conflitos em torno das fronteiras da democracia brasileira (Efrem Filho 2019).

\section{Em nome de uma certa ciência}

As disputas em torno da autoridade científica conformam parte notável das controvérsias que vêm dominando a arena pública brasileira nos últimos anos e têm sido objeto de reflexão na antropologia (Fry \& Carrara 2016; Campos et al 2015). Este é o caso dos já mencionados debates em torno da chamada 'cura gay', que mobilizam argumentos em torno da origem genética da orientação sexual (Gonçalves 2019); das discussões sobre a chamada 'ideologia de gênero' (Correa 2018; Machado 2018; Leite 2019; Machado 2019); e, como não poderia deixar de ser, das altercações em torno da descriminalização do aborto, as quais tensionam o tema da comprovação científica da origem da vida e, como veremos também, a própria validade dos dados científicos que apontam a magnitude do aborto no Brasil. Não raramente, religiosos das mais diferentes denominações mobilizam a autoridade científica como forma de legitimar suas posições no espaço público. Aqui, religião e ciência aparecem em oposições pautadas, de um lado, na pretensão de uma verdade absoluta e, de outro, no falseamento dogmático/ideológico (Cesarino 2018; Luna 2013; Raquentat Júnior 2011; Sales 2014, 2015).

Em relação ao bloco de manifestações contra a adoção da ADPF 442 que mencionaram a religião em sua argumentação, chama a atenção a necessidade de afastamento de qualquer suspeita de motivação religiosa para as justificativas elaboradas, como forma de conferir credibilidade aos argumentos levantados. Ao distanciamento da religião corresponde o imperativo de se aproximar da ciência e da linguagem dos direitos. A fala de Dom Eduardo Hoerpers, representante da CNBB, é paradigmática deste movimento retórico: 
Querem nos desqualificar como fanáticos e fundamentalistas religiosos que querem impor ao Estado laico uma visão religiosa. Onde está o fundamentalismo religioso em aderir aos dados da ciência que comprovam o início da vida desde a concepcão? Onde está o fanatismo religioso em acreditar que todo atentado contra a vida é um crime? Onde está o fundamentalismo em dizer que queremos políticas públicas que atendam à saúde das mães e dos filhos? A CNBB reitera sua posição em defesa da vida em toda sua integridade. Dado científico!

Lilian Sales $(2014,2015)$ já havia indicado a presença dessa estratégia de justificação científica de defesa da vida por parte de agentes da Igreja Católica na ocasião dos debates públicos em torno da liberação de pesquisas com células-tronco embrionárias e da antecipação terapêutica do parto no caso de gestações de fetos anencefálicos. Ao observar a primeira audiência pública da história do Supremo Tribunal Federal, aquela em que se discutiu a constitucionalidade das pesquisas com células-tronco, Naara Luna (2013) percebeu que, apesar de a CNBB figurar como amicus curiae no processo e ter indicado parte dos especialistas ouvidos, nenhum desses especialistas revelou seus vínculos religiosos no plenário, sendo ressaltadas suas qualificações e performances científico-acadêmicas.

De acordo com Lilian Sales $(2014,2015)$, esse recurso à justificação de tipo científico associa-se, nos repertórios dos blocos de expositores favoráveis e contrários às ações, a certa linguagem dos direitos, notadamente dos direitos humanos. Sendo assim, nas exposições de 'defesa da vida em toda a sua integridade', os esforços de produção de distanciamento do arquétipo do 'fanatismo religioso' passam pela demonstração do que seriam dados científicos sobre o início da vida humana, mas também pela definição das normas jurídicas que baseariam tal defesa.

A validação de uma linguagem de direitos no interior das estratégias desencadeadas por atores religiosos não deve, contudo, ser tomada como mera dissimulação retórica. Pelo contrário, precisa ser levada a sério porque alude a formas eficazes de formular problemas e 
configurar práticas religiosas no espaço público. Essa validação esteia conflitos sobre os sentidos dos direitos - o que se está chamando de 'vida', por exemplo - e o reconhecimento ou não dos sujeitos desses direitos. Além disso, como Efrem Filho (2019) percebeu anteriormente, a opção política de atores religiosos pela atuação no interior da linguagem dos direitos assinala um tensionamento das fronteiras - já muito instáveis, porosas e contingentes - entre quem seríamos 'nós' (acadêmicos pertencentes ao campo de estudos de gênero e sexualidade, integrantes de movimentos sociais, feministas, LGBTI+ etc.) e esses 'outros' marcados pela religião, tantas vezes opostos aos 'nossos direitos'.

Esse tensionamento de fronteiras importa sobretudo em razão da centralidade da linguagem de direitos e da noção de direitos sexuais e reprodutivos nos processos mais amplos de mudanças em torno das políticas sexuais, como Sérgio Carrara (2015) tem indicado. Em suas palavras: "tais direitos podem ser considerados como um símbolo da emergência histórica de um 'novo' regime secular da sexualidade, acompanhado por um estilo de regulação moral que lhe é próprio" (Carrara 2015:326). Nesse estilo, avaliam-se capacidades de consentir e responsabilizar-se, que se tornam fundamentais para o reconhecimento de direitos e sujeitos, da 'boa sexualidade' e dos 'legítimos prazeres'. Desse modo, a implicação de atores religiosos em disputas interiores à linguagem de direitos incide tanto nos sentidos dos direitos e dos sujeitos, como argumentamos, quanto na sexualidade mesma enquanto dispositivo, inclusive em suas formas de regulação.

Porém, como dito anteriormente, o movimento recíproco de aproximação da ciência e da linguagem de direitos e de afastamento da religião não foi exclusivo das entidades religiosas durante a audiência pública da ADPF 442. Em sua manifestação durante a audiência, a então professora da Faculdade de Direito da Universidade de São Paulo, agora deputada federal, Janaína Paschoal fez questão de enfatizar que "a discussão não é religiosa!” pois, segundo declarou, "as religiões querem equiparar a vida intrauterina à vida extrauterina e 
não é disso que se trata”. Por sua vez, Angela Vidal Gandra Martins Silva, representante da Associação dos Juristas Católicos (UJUCASP), iniciou sua exposição defendendo a laicidade e o pluralismo e afirmando que não está ali "em nome de uma perspectiva religiosa. Mas como professora de direito, antropóloga, mulher e ser humano”. E sentenciou: "Acolher a ADPF é um aborto jurídico!".

Já Raphael Câmara, indicado pelo Instituto Liberal de São Paulo, alegou sua falta de comparecimento às missas para afastar qualquer suspeita de que seria um 'fanático religioso'. Esse médico também se valeu da legitimidade da ciência em sua argumentação contra a descriminalização do aborto, mas em uma direção diferente da CNBB. Sendo o primeiro expositor a manifestar essa posição e tendo sido antecedido por representantes de várias entidades médicas e científicas que se valeram de diversos resultados de pesquisas para demonstrar a magnitude do aborto ilegal, bem como suas consequências para os altos índices de mortalidade materna no Brasil, o médico afirmou, amparado em sua experiência profissional, que essas informações não passam de mentiras, fruto de estudos enviesados por interesses ideológicos.

A validade científica das estatísticas sobre aborto no Brasil foi alvo de questionamentos, durante toda a audiência, por expositores com as mais diferentes filiações institucionais. Isto se deve ao fato de que tais estatísticas são parte imprescindível dos argumentos arregimentados pelos expositores favoráveis à descriminalização. Números como os divulgados pela Pesquisa Nacional de Aborto estimam que, no Brasil, uma em cada cinco mulheres com até 40 anos já fez pelo menos um aborto (Diniz, Medeiros \& Madeiro 2016). Ainda de acordo com a mencionada pesquisa, mais de 500 mil mulheres interromperam a gravidez de maneira voluntária em 2015.

Estes e outros números foram exaustivamente repetidos ao longo de toda a audiência e são pedra fundamental da controvérsia jurídica em torno da descriminalização, haja vista que, em sendo procedentes, revelam a completa ineficácia da norma penal que criminaliza o abor- 
to. A norma, por um lado, não alcança seu propósito fundamental de proteção da vida e, de outro, coloca as mulheres na clandestinidade e sob risco de perderem suas próprias vidas. Como se argumenta na petição inicial da ADPF 442, tal situação iria de encontro aos princípios constitucionais da razoabilidade e da proporcionalidade, tornando, portanto, os artigos 124 e 126 do código penal de 1940 incompatíveis com os princípios que orientam a Constituição Federal de 1988.

O incremento nos índices de mortalidade materna decorrentes do grande número de abortos ilegais também se coaduna com a ideia de que o aborto deve ser tratado como uma questão de saúde pública e com a noção de que defender a descriminalização também é defender a vida, mas no caso, a vida das mulheres. No entanto, várias das estimativas de internações e mortes causadas por abortos ilegais apresentadas foram questionadas frente aos números oficiais do Ministério da Saúde, mesmo que se contra-argumentasse que a clandestinidade impede que as mulheres busquem atendimento nos serviços de saúde e que, quando o fazem, em geral não possam informar as reais causas de sua situação de saúde por medo de serem criminalizadas.

Ainda quanto às disputas dos números e de sua capacidade de legitimar as justificativas contrárias e favoráveis à descriminalização, outro debate importante se deu acerca dos possíveis efeitos da adoção dos pedidos da ADPF 442 sobre os índices de aborto. Neste caso, representantes das duas posições mobilizaram estatísticas de diferentes países antes e depois da descriminalização do aborto para demonstrar, de um lado, o aumento no número de abortos e, de outro, sua diminuição.

A acirrada disputa em torno da legitimidade científica, que tem seu contrapeso na suspeição em torno das motivações religiosas ou ideológicas das(os) expositoras(es), alcançou seu ponto alto na fala de José Paulo Silva, procurador e representante do estado de Sergipe:

Se questiona a laicidade do Estado. Eu digo que se há um agrupamento que não precisa de lei penal, são os cristãos [...] O católico não precisa disso. $\mathrm{O}$ católico é punido com a excomunhão. [...] 
Tanto quanto a religião, o feminismo é um ato de fé e esse ato é subsidiado em dogmas. E esses dogmas motivam posturas. Por exemplo a crença na pesquisa que foi feita em 2010 e 2016 é um ato de fé e se afirma como verdade absoluta que a cada cinco mulheres, uma já abortou.

A exposição do procurador é exemplar e sintetiza o duplo movimento retórico mencionado anteriormente. De pronto, os representantes de entidades religiosas buscam levar à arena pública argumentos seculares em prol da manutenção da criminalização do aborto como forma de legitimar sua posição. Assim, parece haver um consenso de que é o uso da razão, que tem sua expressão máxima na ciência positivista e sob a qual não pode recair qualquer suspeita, que deve orientar o debate público sobre a questão do aborto. A ciência é portanto trazida para o debate por esses atores e atrizes através de frases de impacto, tais como "a embriologia é quem define o início da vida" ou "é fato científico comprovado", para endossar a posição de que a vida deve ser protegida desde a concepção.

Entretanto, se ramos das ciências naturais - como a biologia, a genética e a embriologia - são fonte de legitimidade, segundo os argumentos de grande parte do grupo contrário à descriminalização, o mesmo não pode ser dito das pesquisas notadamente oriundas das ciências humanas que buscam compreender a magnitude do aborto no Brasil. Nesse sentido, a validade de dados científicos é colocada sob questão a partir de sua aproximação a elementos que supostamente falseariam a realidade, como o dogma e a ideologia.

Esta estratégia não é recente. Ela também pôde ser observada, por exemplo, durante a polêmica entrevista de Silas Malafaia a Marília Gabriela, em seu prestigiado e extinto programa 'De frente com Gabi', em 03 de fevereiro de 2013. Na entrevista, o pastor afirmou enfaticamente que "ninguém nasce gay, homossexualismo é um comportamento". Diante da reação de Marília Gabriela que o interrompe afirmando "Isso é contestável!", ele continua: "Isso é contestável? Eu mando vir lá da genética! Quem é que pode dizer que uma pessoa nas- 
ce gay ou não? Não é a psicologia, é a genética. É a ciência que pode dizer. É igual aborto. Quem é que pode dizer onde começa a vida? A biologia”. À época, esta entrevista ensejou intensa controvérsia pública sobre o fazer científico e sua relação com a política devido ao fato de um biólogo e geneticista haver gravado um vídeo em resposta a Malafaia, reivindicando a origem genética da homossexualidade como forma de se opor à proposta de 'cura gay' do pastor (Fry \& Carrara 2016).

Se, na fala do procurador de Sergipe, levar a sério a pesquisa nacional sobre aborto se converte em um ato de fé porque contaminado pelo feminismo, Silas Malafaia estabelece uma hierarquia entre os saberes oriundos da psicologia e da genética, desautorizando inclusive qualquer outra ciência a emitir considerações acerca da origem da homossexualidade. A biologia, afinal, é 'a ciência que pode' dizer algo.

Ambos os movimentos retóricos remetem a um contexto político mais amplo no qual os conhecimentos produzidos pelas ciências humanas se encontram sob o ataque constante de setores conservadores no país (Carrara, França \& Simões 2018). É neste cenário que integrantes da Bancada Parlamentar Agropecuária da Câmara dos Deputados instauram uma Comissão Parlamentar de Inquérito para questionar pareceres antropológicos que fundamentam a demarcação de terras indígenas e quilombolas e em que se retira o conceito de gênero do Plano Nacional de Educação, sob a acusação de tratar-se de uma 'ideologia' (Machado, Motta \& Facchini 2018; Leite 2019). Paralelamente à acusação de certas ciências como contaminadas ideologicamente porque comprometidas com a defesa dos direitos de diversas populações, emerge o recurso retórico a uma política pretensamente neutra e imparcial.

\section{A maioria perseguida}

A exposição de Douglas Baptista, da Convenção Geral das Assembleias de Deus, trouxe argumentos semelhantes aos de representantes de outras entidades religiosas, tais como a acusação de ativismo judi- 
cial por parte do STF, a defesa da vida desde a concepção, a inconstitucionalidade da ADPF 442 e o questionamento dos dados sobre o aborto no Brasil. Entretanto, o pastor trouxe a religião para o centro do debate a partir de duas estratégias que já foram observadas por outros autores que se têm debruçado sobre a atuação de parlamentares e pastores evangélicos brasileiros em debates públicos importantes (Camurça 2017; Luna 2018). Na primeira delas, a religião se configura como fonte de legitimidade para sua posição contra a descriminalização do aborto devido à ligação umbilical da cultura nacional aos valores cristãos.

Nossas igrejas comportam 22 milhões de brasileiros entre membros e congregados, nos mais de 100 mil templos-sede em todo o território nacional. Estes dados caracterizam a elevada representatividade das Assembleias de Deus na sociedade brasileira. [...] Esta ADPF não pode prosperar porque está em desacordo com a moral razoável dos brasileiros. Indiscutivelmente a prática do aborto é reprovável para a maioria da sociedade brasileira. Revela o Censo de 2010 que mais de $85 \%$ dos brasileiros professam a fé cristã. E o ato de tirar a vida de outrem, seja embrião, feto, criança, jovem, adulto, idosos, saudável ou doente, é um atentado à lei da ética e da moral cristã, pois viola o sexto mandamento do decálogo bíblico que diz: não matarás. Discute-se que a questão em debate não pode ter parâmetro religioso. E que somos fundamentalistas, fanáticos, extremistas, dentre outros termos pejorativos. Simplesmente porque insistimos em defender a cultura judaico-cristã. Diante disto, eu me pergunto: desde quando que ter convicções religiosas, acreditar em Deus e ter a vida pautada na ética e na moral cristã tornou-se um ato criminoso nesta nação? O Brasil não é um país totalitário, fascista, socialista, marxista, ou ateu. Vivemos em um estado democrático de direito, em que a liberdade de pensamento, liberdade de expressão, de consciência e de crença nos são assegurados pelo texto constitucional e requeremos que nosso direito seja respeitado.

É interessante perceber como a demonstração de representatividade vai-se ampliando ao longo de seu discurso. Inicialmente, o pastor afirma representar os 22 milhões de brasileiros integrantes da Assembleia de Deus, o que já seria bastante significativo. Em um segundo momento, ele amplia expressivamente esse escopo para os $85 \%$ 
da população brasileira que se declaram cristãos, para finalmente colocar-se como defensor da cultura judaico-cristã, algo que certamente ultrapassa os limites de qualquer Estado-nação. Dessa maneira, o que se está a defender não são simplesmente valores e moralidades religiosas, mas a própria cultura nacional e ocidental.

Ao abordar diversas situações em que o lugar da religião no espaço público brasileiro esteve sob questão, Marcelo Camurça (2017) demonstra como esta mesma estratégia, de evidenciar como valores religiosos estão imiscuídos à cultura nacional, foi utilizada por agentes das igrejas católica e evangélicas em outras ações contra a ampliação de direitos e também para a garantia da presença de símbolos religiosos em ambientes públicos. A argumentação de católicos e evangélicos para a manutenção de crucifixos e bíblias em praças e Assembleias Legislativas se fundamentou no argumento de que estes são símbolos universais, inspiradores de valores humanistas, independente de crenças religiosas.

Ao mesmo tempo que se coloca como representante de uma maioria inquestionável, no segundo momento de sua argumentação, o pastor apresenta esta maioria religiosa/cultural como vítima de possíveis ameaças totalitárias que poriam em risco suas liberdades. Colocar-se como vítima de perseguições serve tanto para afastar possíveis acusações de fanatismo e fundamentalismo, que podem ser concebidos como outras expressões totalitárias, como também permite o estabelecimento de uma conexão com repertórios que estavam em evidência no contexto eleitoral que o Brasil atravessava no momento da realização da audiência, em 2018. O suposto ateísmo comunista/socialista/marxista foi amplamente difundido como uma ameaça à soberania nacional e às liberdades individuais citadas pelo pastor e também pela campanha do agora presidente Jair Bolsonaro. Não por acaso, o candidato contou com o apoio público de um dos mais proeminentes pastores da Assembleia de Deus, Silas Malafaia, e com ampla maioria do 'voto evangélico' no segundo turno das eleições ${ }^{8}$. 
A segunda estratégia de que se valeu o pastor Douglas Baptista, portanto, foi a de apresentar-se como membro de uma 'maioria perseguida'. Esta estratégia, porém, não consiste numa exclusividade das denominações evangélicas. Vaggione (2012) demostra como agentes da Igreja Católica concebem o avanço da agenda dos direitos sexuais e reprodutivos como uma ameaça não apenas à sua cosmovisão religiosa, mas à 'cultura da vida'. Tendo em vista a relação necessária que a doutrina católica estabelece entre sexualidade e reprodução, qualquer iniciativa que se paute na separação destas esferas da vida é antagonizada como produtora de uma cultura da morte. Nesse sentido, apesar do fundamento doutrinário da sua posição, a Igreja Católica consegue empreender a tradução desse fundamento através do valor mais universal possível: a defesa da vida - o que ratifica a premência da linguagem de direitos, como discutimos.

Ao questionar a legitimidade dos ministros do Supremo Tribunal Federal para decidirem sobre a matéria, o representante da Convenção Geral das Assembleias de Deus acusa a Corte de ser um agente simpatizante de ideologias e da própria ameaça totalitária que mencionou anteriormente. A descriminalização em debate no STF é então concebida como uma tentativa de mudar os próprios valores do povo brasileiro: "Não cabe a este tribunal mudar a moral do povo". Interessa, no entanto, o fato de que um pretenso representante de uma 'maioria perseguida' vem a público, durante uma audiência no interior do Supremo, questionar a legitimidade de um tribunal que, sendo uma Corte Constitucional, costuma ser compreendido sobretudo por sua função contramajoritária, a qual supõe a imposição de limites a maiorias em razão da proteção de direitos e garantias individuais de minorias.

Não à toa, a categoria 'minoria' é intensamente mobilizada nos votos dos ministros do Supremo em casos relativos a controvérsias públicas de gênero e sexualidade, principalmente naqueles atinentes à diversidade sexual e de gênero, ou seja, quando a minoria de que se trata pode ser apreendida como LGBTI ${ }^{9}$. Ao analisarem os votos dos 
ministros do STF em parte significativa desses casos, Vieira e Efrem Filho (2020) notaram que, naquelas narrativas judiciais, 'minorias' constituem condição de possibilidade para a ação dos ministros, para as disputas que os ministros travam em nome de certos sujeitos, em sua proteção ${ }^{10}$. Sendo assim, o ataque à legitimidade dos ministros do STF de decidirem sobre a controvérsia do aborto acaba condensando ataques à legitimidade dos ministros para julgar um relevante conjunto de casos implicados em controvérsias públicas relativas a gênero e sexualidade ${ }^{11}$. Condensa ainda, mais profundamente, ataques à legitimidade do próprio Supremo Tribunal Federal, cuja função contramajoritária é posta em xeque por ameaçar uma suposta maioria, a 'moral do povo'.

Em oposição a tal ameaça estaria, segundo o pastor Douglas Baptista, o Poder Legislativo. Este seria, devido à sua legitimidade representativa, o devido guardião dos valores nacionais. A menção ao pluralismo religioso, presente no Legislativo segundo o expositor, também serve de garantia contra qualquer possível acusação de fundamentalismo, haja vista que remete às ideias de convivência pacífica e tolerância entre diferentes credos.

Igualmente estamos apreensivos com os excessos advindos da cultura jurídica pós-positivista que busca ir além da legalidade, que ultrapassa a letra da lei, permitindo ao julgador ser simpatizante de ideologias e assim emitir juízos valorativos a fim de atender a aspirações de supostos direitos de militâncias diversas. [...] Assim, a eventual procedência da sobreditação, data vênia, seria uma imposição autoritária e ilegal em discordância com a ética e a moral dos brasileiros [...]. Salienta-se ainda que o pluralismo religioso e o debate democrático representativo para a promulgação de leis encontra sua guarida no Congresso Nacional. Portanto, é lá, por meio dos representantes eleitos pelo povo, que se garante a vontade majoritária.

Em sua exposição, portanto, Douglas Baptista enfatizou a incompetência dos ministros do Supremo para incidir sobre a controvérsia do aborto e demonstrou suas preocupações com o que seriam os 'ex- 
cessos' de uma 'cultura jurídica pós-positivista' influenciada por 'ideologias' contrárias ao que seriam 'a ética e a moral dos brasileiros' - ou seja, não somente de determinados segmentos religiosos, mas da nação ou da 'cultura nacional'. Reciprocamente, o pastor ressaltou a legitimidade do Congresso Nacional para a apreciação da questão, dado que esta instância estatal corresponde aos critérios de legitimidade da representação democrática e do pluralismo religioso. Aqui, Baptista traz a religião para o debate público, mas não para persuadir os ministros do Supremo de que a moral religiosa deva guiar suas decisões. De um lado, faz a religião emergir para logo em seguida ser sutilmente englobada e apagada pelas noções de cultura e valores nacionais, e, de outro lado, identifica o Congresso Nacional como o lócus privilegiado do pluralismo religioso e, assim, da democracia. No limite dessa chave retórica, a religião não se opõe à democracia, oportuniza-a.

\section{Colocando a religião na arena pública em nome da laicidade}

Se, como visto, defensores da manutenção da criminalização do aborto se preocuparam em afastar as suspeitas sobre possíveis motivações religiosas - ou pelo menos fundamentalistas/ fanáticas - acerca de sua posição, o grupo pró-escolha coloca a religião na arena do debate de maneiras diversas. Os pronunciamentos de Lusmarina Campos Garcia, do Instituto de Estudos da Religião (ISER), Maria José F. Rosado Nunes, das Católicas Pelo Direito de Decidir, e do Rabino Michel Schlesinger, representante da Confederação Israelita do Brasil, são por certo exceções à regra que historicamente situa religiosos e defensores da legalização do aborto em lados opostos. Assim, estes agentes religiosos ofereceram interpretações dos textos bíblicos e, no caso de Rosado Nunes, de atos recentes do Papa Francisco que não colocariam em oposição a descriminalização do aborto e a tradição religiosa.

O núcleo do argumento de Lusmarina e Schlesinger se encontra nas passagens bíblicas nas quais a prática do aborto é autorizada, indicando portanto que, segundo o texto sagrado, a vida do feto/embrião 
não tem o mesmo valor que a de uma pessoa nascida. A primeira passagem versa sobre a punição para o homem que causar aborto em mulher durante uma briga com seu marido. A pena estipulada é de multa e não de morte. Isto seria importante pois naquele momento vigorava a lei mosaica do 'olho por olho, dente por dente', ou seja, segundo esta lógica, aborto não se trataria de assassinato.

$\mathrm{Na}$ outra passagem bíblica citada, menciona-se a possibilidade de realização de um aborto ritual, praticado por um sacerdote, em caso de suspeita de infidelidade. Portanto, se um aborto causado por outrem não é punido com a morte e se em algumas situações pode ser praticado por um sacerdote, isto significaria que, segundo os textos bíblicos, o valor da vida não é absoluto e a vida intrauterina não guarda o mesmo valor da vida de uma pessoa nascida. Lusmarina acrescentou ainda que, nos textos bíblicos, há 108 passagens em que Deus manda matar mulheres, meninas, meninos e varões adultos. E que mesmo o sexto mandamento, 'não matarás', mencionado por exemplo pelo pastor Baptista, possuiria exceções, não se aplicando a estrangeiros, inimigos de Israel e adúlteras.

Lusmarina prosseguiu sua exposição denunciando a exclusão das mulheres dos espaços de poder da Igreja e a consequente manipulação da interpretação do texto bíblico pelo patriarcado eclesial. Evocou o perdão concedido por Jesus à mulher adúltera e os valores do perdão e acolhimento pregados pela Igreja. Ao final, evocou a laicidade a partir da interpretação de Lutero sobre qual deve ser a relação entre os reinos secular e espiritual.

Tais exposições, ainda que minoritárias, promovem uma reorganização nas coalizões e disputas em jogo. A fronteira antagônica estabelecida entre religiosos e defensores dos direitos das mulheres é posta em suspensão e se desloca para a disputa que se estabelece sobre a interpretação mais adequada do texto bíblico. Evidencia-se, então, a existência mesma da disputa, de diferentes interpretações do sagrado e, portanto, expõe-se os conflitos políticos interiores às práticas e organizações religiosas, do que se depreende que as posições religiosas 
sobre determinada controvérsia são elas próprias - e não os dados da Pesquisa Nacional de Aborto, as feministas ou o Supremo Tribunal Federal - eivadas de 'ideologias'.

Análogo movimento de denúncia da imparcialidade em nome da laicidade é realizado durante a exposição conjunta do Coletivo Margarida Alves de Assessoria Popular, da Rede Feminista de Juristas (DEFEM), do Criola, do Coletivo Feminista Sexualidade e Saúde (CFSS) e do Grupo Curumim, todas reconhecidas organizações feministas. É contundente sua denúncia da atuação indevida de entidades religiosas, sobretudo cristãs, com vistas a impedir a promoção dos direitos das mulheres no âmbito da política nacional. Conforme sua arguição, a atuação de parlamentares baseada em valores religiosos resultaria, portanto, na falta de legitimidade do Legislativo para decidir sobre questões como o aborto.

Este argumento esteve presente não apenas nas falas das representantes das organizações feministas mencionadas, mas também compôs parte das estratégias argumentativas de representantes de entidades científicas e jurídicas que se colocaram a favor da adoção dos pedidos da ADPF 442. Desse modo, contra a conclusão segundo a qual competiria ao Legislativo, em razão de sua pretensa pluralidade e de sua natureza representativa, a competência para decidir sobre controvérsias como o aborto, as/os expositoras(es) favoráveis à descriminalização ratificaram a competência do Supremo Tribunal Federal e acusaram o parlamento de ilegitimidade, exatamente por conta das fortes implicações religiosas dos parlamentares e do seu déficit de pluralidade e representatividade, haja vista a persistente sub-representação de mulheres no Congresso Nacional.

\section{Considerações Finais}

Retomando a questão proposta por Paula Montero (2012) sobre as formas legítimas para formulações e resoluções de controvérsias, podemos afirmar que, no tocante ao debate sobre a descriminalização do aborto, a religião se configura de maneira multifacetada no espaço 
público brasileiro. Tais configurações sintetizam os mais relevantes debates sobre qual deve ser o papel das religiões públicas nas sociedades ocidentais secularizadas, bem como as diferentes traduções e usos das noções de laicidade e pluralismo religioso no Brasil.

Uma primeira questão emblemática está no confronto entre distintas noções de ciência. Como explicado no transcurso deste texto, os expositores contrários aos pedidos da ADPF 442, muitos deles autodenominados religiosos, esforçaram-se para justificar cientificamente a defesa da vida desde a concepção, valendo-se de dados da biologia, da genética e da embriologia, por exemplo, enquanto opuseram-se aos dados decorrentes de pesquisas situadas nas ciências humanas, em especial à Pesquisa Nacional de Aborto, deslegitimando-a como mera 'ideologia' ou mesmo equiparando-a a um 'ato de fé' como qualquer outro.

De uma parte, as estratégias de justificação de agentes religiosos no debate público passam por sua tradução à linguagem secular, o que inclui sua ancoragem em argumentos científicos e sua inserção conflitiva numa linguagem de direitos, como dito. Por outra parte, no entanto, essas estratégias validam somente certos saberes científicos, manejando-os com vistas à obliteração da legitimidade de outros campos do saber: a afirmação de que 'acreditar' na Pesquisa Nacional do Aborto consiste num 'ato de fé' reduz os métodos das ciências sociais a simples subjetivismo, permitindo assim a sua identificação como 'ideologia' e, reciprocamente, anunciando a autêntica possibilidade de simplesmente 'acreditar' no contrário, ou seja lá no que for. Há, como se vê, negação de objetividade.

Esta forma subjetivista de compreender 'ciência' volta-se à deslegitimação das ciências humanas e sociais (embora, em certos contextos, não apenas delas) e afeta sobremaneira o campo dos estudos de gênero e sexualidade, alvo prioritário das denúncias de 'ideologia' - no caso, 'ideologia de gênero' (Correa 2018; Machado 2018; Leite 2019; Machado 2019). Além disso, impõe às ciências humanas e sociais o premente desafio de ratificar a objetividade do conhe- 
cimento científico derivado de suas próprias metodologias, porém sem perder de vista a inexorável situacionalidade de todo conhecimento (Haraway 1995).

Como habilmente notaram Sérgio Carrara, Isadora Lins França e Júlio Assis Simões (2018) ao discutirem o tema,

"é preciso que encontremos um ponto de equilíbrio entre, de um lado, a afirmação de que o conhecimento que produzimos é necessariamente situado - política e epistemologicamente - e, portanto, jamais 'neutro'; e, de outro, a defesa da autonomia (relativa por certo) do campo científico e das convenções que o regem” (Carrara, França \& Simões 2018:76).

Tratar-se-ia, dessa maneira, de insistir que um conhecimento científico politicamente implicado não se confunde com ideologia, opinião ou tampouco crença, porque as pesquisas empreendidas nas ciências humanas e sociais não dispensam rigor lógico, conceitual e metodológico.

Uma segunda questão relevante parece indicar como diferentes concepções de laicidade resvalam em um importante debate acerca das funções de agentes dos poderes Judiciário e Legislativo. As presenças de entidades das mais diversas religiões (candomblecista, espírita, católica, judia e de diversas denominações evangélicas) no rol de especialistas arregimentados para se pronunciarem na audiência, assim como as falas iniciais das Ministras Rosa Weber e Cármen Lúcia, apontam para uma noção de laicidade pautada na ideia de pluralismo religioso, a partir da qual o Estado deve observar um tratamento igualitário à diversidade religiosa, sem, contudo, negar sua existência e sua relevância. O Poder Judiciário figuraria, assim, como o guardião último deste princípio.

Por sua vez, a acusação de ativismo judicial baseado em ideais 'pós-positivistas' emerge como denúncia do que seria a contaminação ideológica do Judiciário e, portanto, de sua incompetência para julgar a matéria. Tal contaminação ideológica ou religiosa não parece ser um problema no caso do Poder Legislativo, pois tratar-se-ia de uma instân- 
cia estatal munida de representatividade. Nele estariam presentes as moralidades religiosas, que se confundem à cultura e aos valores nacionais. A manifestação das representantes do movimento feminista tomam este fato (aliado à baixa representatividade das mulheres na casa legislativa) como motivo de denúncia da falta de capacidade dos parlamentares para decidir sobre controvérsias públicas como a do aborto. Assim, reivindica-se a competência dos ministros do Supremo para julgar sobre a matéria porque a priori não seriam eles contaminados por motivações religiosas.

Essas acusações cruzadas acerca da presença ou da ausência de legitimidade, representatividade, pluralismo religioso, laicidade, ativismo judicial, cientificidade e influências religiosas ou ideológicas costumam desdobrar-se no interior de uma linguagem de direitos e referir-se às formas que as disputas políticas assumem no campo jurídico, com suas performances particulares. Controvérsias públicas de gênero e sexualidade como a do aborto parecem, entretanto, levar esses desdobramentos ao extremo, expondo frinchas e tensões do campo jurídico, da experiência democrática, dos conflitos entre agentes políticos e instâncias estatais centrais e, inclusive, distintas concepções do que seja democracia.

É assim que uma audiência pública no Supremo Tribunal Federal sobre a descriminalização do aborto até a 12a semana de gestação oportuniza críticas e ataques à legitimidade da Corte próximos ou similares àqueles protagonizados, nos interstícios da crise democrática que nós atravessamos, por agentes políticos conservadores e de extrema-direita ${ }^{12}$. Entre esses agentes, como se sabe, encontra-se o Presidente da República, Jair Bolsonaro, cujas notórias tensões com os ministros do Supremo, quem ele acusa frequentemente de 'ativismo' e desrespeito à chefia do Executivo e à separação dos poderes ${ }^{13}$, levaram-no a justificar a indicação de um 'ministro terrivelmente evangélico’ para o tribunal, André Mendonça. Esta indicação, segundo Bolsonaro afirmou, responderia à ausência de pluralismo religioso no STF, que ainda não possuiria um ministro evangélico ${ }^{14}$. 
A potência do aborto para incitar e conectar disputas políticas dessa grandeza exprime, portanto, que gênero e sexualidade tanto consistem em objeto de intensas controvérsias públicas quanto participam profundamente da própria feitura dos conflitos acerca das fronteiras da democracia. A audiência pública ocorrida nas dependências do Supremo Tribunal Federal em 03 e 06 de agosto de 2018, alguns meses antes das eleições presidenciais e das massivas mobilizações em torno do \#EleNão, jogava luz sobre históricas reivindicações de direitos sexuais e reprodutivos, mas não se continha nelas: tratando-as, ensejava tomadas de posição sobre até onde é possível ir a experiência democrática. Esta pode encerrar-se na identificação do 'pluralismo religioso' e da 'representatividade' supostamente presentes no Congresso Nacional; ou pode converter-se em horizonte político, objeto das mobilizações sociais e reivindicações por direitos que, na Corte ou fora dela, empenham-se em denunciar e enfrentar as desigualdades sociais - de gênero e sexualidade, inclusive - que impedem a democracia desejada, aquela que os critérios formais de 'pluralismo' e 'representatividade' não são capazes de consubstanciar.

\section{Notas:}

1 Em sua página on-line, a Anis: Instituto de Bioética apresenta-se como uma organização feminista, sem fins lucrativos, que "busca promover cidadania, igualdade e Direitos Humanos para mulheres e outras minorias". Fundada em 1999, com sede em Brasília, trata-se da primeira organização não-governamental voltada a práticas de pesquisa, assessoramento e capacitação em bioética na América Latina. Segundo aponta Alba Ruibal (2020), integrantes da ANIS têm papel crucial na litigância estratégica que levou, em diferentes momentos, o tema do aborto para o Supremo Tribunal Federal, a começar pelas discussões em torno da ADPF 54, ajuizada ainda em 2004 e relativa à descriminalização do aborto em casos de anencefalia. De acordo com Ruibal, "em 2004, [o STF] se converteu na primeira corte constitucional da América Latina a receber uma demanda originada em litígio estratégico, conduzido por uma organização feminista, pela ampliação do direito ao aborto" (2020:1168). Para a descrição dos percursos políticos e argumentativos que acompanharam a ADPF 54 no ṠTF, ver Diniz (2014). 
2 Conforme o art. 124 do Código Penal, é punível com pena de detenção de 01 a 03 anos quem "provocar aborto em si mesma ou consentir que outrem lho provoque". Por sua vez, dispõe o art. 126 do mesmo Código que "provocar aborto com o consentimento da gestante" é ato típico punível com pena de reclusão de 01 a 04 anos. Como se sabe, há duas hipóteses de 'aborto legal' praticáveis por médicos e previstas no art. 128 do Código Penal: a) a do "aborto necessário", "se não há outro meio de salvar a vida da gestante"; e b) a do "aborto no caso de gravidez resultante de estupro", que se dá "se a gravidez resulta de estupro e o aborto é precedido de consentimento da gestante ou, quando incapaz, de seu representante legal”. Há ainda uma terceira hipótese permissiva para a realização do aborto no Brasil, a dos casos de anencefalia. Esta última hipótese decorreu da decisão dos ministros do STF junto à mencionada ADPF 54, ajuizada em 2004, mas julgada apenas em abril de 2012.

3 Alguns exemplos de iniciativas legislativas que visam à restrição do acesso ao aborto legal: 01) PL 2893/2019 - de Chris Tonietto (PSL/RJ) e Filipe Barros (PSL/ PR) - revoga o art. 128 do Código Penal, passando a punir o aborto praticado por médico mesmo nos casos de risco de vida para a mulher ou gravidez resultante de estupro; 02) PL 1923/ 2019 - do Senador Fabiano Contarato (REDE/ES) - altera o Código Penal para prever o crime de lesão corporal da vida humana intrauterina, inclusive na modalidade culposa; 03) PEC 164/2012 - de Eduardo Cunha (PMDB/ $\mathrm{RJ}$ ) e João Campos (PSDB/GO) - altera o art. 5० da Constituição para estabelecer o direito à vida desde a concepção; 04) PL 891/2015 - do deputado Flavinho (PSB/ $\mathrm{SP})$ - estabelece as políticas públicas no âmbito da saúde sexual e dos direitos reprodutivos e dá outras providências, garantindo a inviolabilidade da vida do nascituro; 05) PL 3406/ 2019 - do Senador Eduardo Girão (Podemos/CE) - dispõe sobre o Estatuto da Gestante e da Criança por Nascer, em seu art. 20 explicita que "o conceito de criança por nascer compreende todo o período de gestação, a partir do momento da concepção, incluindo os seres humanos concebidos 'in vitro', mesmo antes da transferência para o útero da mulher"; 06) PL 4642/2016 - do Deputado Flavinho (PSB/SP) - Desarquivado em 20/02/2019, dispõe sobre a prevenção e a conscientização dos riscos e consequências relacionados ao aborto.

4 De fato, a ADPF 54 consistiu no primeiro grande caso em que setores de movimentos sociais e da sociedade civil mobilizaram-se para a reivindicação de direitos sexuais e reprodutivos perante o STF. O caso da antecipação terapểutica do parte de anencéfalos precedeu e abriu espaço para, por exemplo, as reivindicações em torno: das uniões estáveis entre pessoas do mesmo sexo (ADI 4277 e ADṔF 132); do reconhecimento da constitucionalidade de dispositivos da Lei Maria da Penha (ADC 19); da descriminalização de "pederastia ou outro ato de libidinagem" no Código Penal Militar (ADPF 291); da substituição de prisão preventiva por prisão domiciliar nos casos de mulheres presas gestantes ou mães de crianças de até 12 anos ou de pessoas com deficiência (HC 143641); da alteração de registro civil de travestis e transexuais (ADI 4275); da criminalização da homofobia e da transfobia (ADO 26 e MI 4733); da permissão para doação de sangue por homens que vivenciam práticas sexuais com outros homens (ADI 5543); e das chamadas 'Leis da Mordaca', as legislações municipais que proíbem a tematização de gênero e sexualidade nas escolas (ADPF 457). 5 O Supremo Tribunal Federal é a única corte constitucional do mundo a televisionar e transmitir os seus julgamentos, o que se dá por meio de um canal público 
de televisão, a TV Justiça, assim como através dos perfis do STF e da TV Justiça no Youtube. A esse respeito, Vieira \& Efrem Filho (2020) argumentam que tal peculiaridade da Corte brasileira relaciona-se às formas como os ministros decidem, procedimentalizam seus julgamentos e formalizam suas decisões nos acórdãos, práticas estas que aludem a modos de 'deixar-se ver a claro' e incidem em densos debates sobre as posições dos ministros e do próprio Supremo em nossa experiência democrática. No caso da audiência pública sobre o aborto, esse 'deixar-se ver' teve como consequência, por exemplo, a rápida disseminação de trechos das falas dos expositores em grupos de WhatsApp e redes sociais. Se, nos grupos em que estamos, exposições como a da professora Debora Diniz circularam imensamente, imaginamos que as exposições contrárias à descriminalização hajam circulado com igual ou maior eficácia em grupos mais porosos a essa posição.

6 Mantivemos a expressão 'defesa da vida' entre aspas porque concerne a uma categoria sob intensa disputa no campo. Tanto as/os agentes que defendem a descriminalização do aborto como aquelas(es) que se posicionam contra colocam-se publicamente como defensoras(es) da vida. Lia Zanotta Machado (2017) explica que, no interior dessas disputas, feministas adotam a distinção entre 'vida vivida' e 'vida abstrata', sendo esta última compreensão advinda de 'argumentos religiosos' que sustentam 'direitos absolutos do concepto desde a fecundação'. Os termos nos quais tais disputas se desenrolam serão tratados ao longo deste artigo. Entretanto, importa notar que, usualmente, os atores políticos e organizações reconhecidos pela alcunha de 'defesa da vida' ou 'pró-vida' são aqueles contrários à descriminalização do aborto.

7 Apesar de o ISER se identificar como uma organização da sociedade civil de caráter laico, mantivemo-lo neste texto entre as 13 entidades religiosas por dois motivos sobremaneira: a) sua representação na audiência foi realizada por Lusmarina Campos Garcia, uma pastora que assim se apresentou ao público; e b) sua participação na audiência compôs o bloco de intervenções das entidades religiosas, programado para a manhã da segunda-feira, dia 06 de agosto de 2018, pela ministra Rosa Weber e/ou por seus assessores, o que nos faz crer que os próprios agentes judiciais compreenderam o ISER como uma entidade religiosa.

8 Em artigo recente, Ronaldo de Almeida (2019) procedeu à análise desse 'voto evangélico', situando-o em meio ao que vem chamando de 'crise brasileira' e no denso campo de moralidades a que essa crise se articula.

9 Dentre esses casos relativos à diversidade sexual e de gênero, pode-se citar as ações sobre as uniões estáveis entre pessoas do mesmo sexo (ADPF 132 e ADI 4277), a criminalização da homofobia e da transfobia (ADO 26 e MI 4733) e a alteração de registro civil de travestis e transexuais (ADI 4275).

10 As análises de disputas judiciais pelo reconhecimento de direitos atinentes à diversidade sexual e de gênero têm ressaltado a participação dessas disputas na constituição dos sujeitos que se anuncia intencionar proteger. Isto se dá, por exemplo, na constituição dos 'homoafetivos', transexuais e travestis como populações minoritárias delimitáveis e apreensíveis através de uma gramática de sofrimentos. Para discussões a esse respeito, ver: Efrem Filho (2014); Freire (2016); Coacci (2020); Vieira \& Efrem Filho (2020); 
11 Adriana Vieira e Roberto Efrem Filho (2020) demonstram, no entanto, que em casos em que 'mulheres' são constituídas como o sujeito de direitos a ser protegido, a noção de 'minoria' perde espaço para o adjetivo 'vulneráveis', de modo que as mulheres são identificadas a partir de suas vulnerabilidades. Isto ocorre, por exemplo, nos votos dos ministros sobre a constitucionalidade de dispositivos da Lei Maria da Penha (ADC 19), a dispensa de representação da vítima em casos de lesões corporais de natureza leve, em situação de violência doméstica e familiar contra a mulher (ADI 4424) e a substituição de prisão preventiva por prisão domiciliar nos casos de mulheres presas gestantes ou mães de crianças de até 12 anos ou de pessoas com deficiência (HC 143641). No julgamento da ADPF 54, a ação sobre o aborto de fetos anencéfalos, a categoria 'minoria' aparece, nas palavras do então ministro Celso de Mello, como "critério das vulnerabilidades das mulheres": "Não podendo ser numericamente reportadas como um grupo minoritário, as mulheres tornam-se minoria à medida de sua vulnerabilização" (Vieira \& Efrem Filho 2020:1111).

12 Críticas, ataques e protestos capitaneados por atores políticos de extrema-direita contra o Supremo Tribunal Federal têm-se multiplicado nos últimos anos. Recentemente, em fevereiro de 2021, acarretaram inclusive na polêmica prisão em flagrante do Deputado Federal Daniel Silveira (PSL-TJ), decretada inicialmente pelo Ministro Alexandre de Moraes, junto ao 'Inquérito das Fake News', mas confirmada posteriormente pela unanimidade dos ministros do Supremo. Em maio de 2020, um grupo de extrema-direita que se apresenta como '300 do Brasil' realizou protesto diante do edifício do STF, em Brasília, valendo-se de uma estética semelhante à utilizada nas manifestações dos racistas norte-americanos da Ku Klux Klan. Para informações sobre a prisão de Daniel Silveira, ver: https://portal.stf.jus.br/noticias/ verNoticiaDetalhe.asp?idConteudo=460657\& ori=1. Acesso em 30/04/2021. Para a descrição do ato dos '300 do Brasil', ver: https://congressoemfoco.uol.com.br/ governo/bolsonaristas-copiam-klu-klux-klan-em-ato-contra-stf-veja-o-video/.

13 São muitos os exemplos das tensões protagonizadas por Jair Bolsonaro contra os ministros do STF. Um dos mais emblemáticos se deu em maio de 2020, quando o Presidente da República reagiu, diante de câmeras televisivas, à decisão do ministro Alexandre de Moraes que, no interior do 'inquérito das fake news', autorizou mandados de busca e apreensão em endereços de aliados de Bolsonaro: "As coisas têm limite. Ontem foi o último dia e peço a Deus que ilumine as poucas pessoas que ousam se julgar mais poderosas que outros que se coloquem no seu devido lugar, que respeitamos. E dizer mais: não podemos falar em democracia sem Judiciário independente, Legislativo independente para que possam tomar decisões. Não monocraticamente, mas de modo que seja ouvido o colegiado. Acabou, porra". Para uma lista dos ataques, ver a seguinte matéria do site Migalhas: https://www.migalhas.com.br/quentes/343340/ministros-do-stf-sao-alvos-de-frequentes-ataques-de-bolsonaro. Acesso em 30/04/2021.

14 "Com todo respeito ao Supremo Tribunal Federal, eu pergunto: existe algum, entre os 11 ministros do Supremo, evangélico? Cristão assumido? Não me venha a imprensa dizer que eu quero misturar a Justiça com religião. Todos nós temos uma religião ou não temos. E respeitamos, um tem que respeitar o outro. Será que não está na hora de termos um ministro no Supremo Tribunal Federal evangélico?" - disse Jair Bolsonaro, em 31 de maio de 2019, em reação à decisão 
dos ministros do STF que levou à criminalização da homofobia e da transfobia, em razão do julgamento da ADO 26 e do MI 4733. Na mesma ocasião, Bolsonaro acusou os ministros de estarem legislando. Para acesso à matéria do G1 sobre as declarações de Bolsonaro, ver: https://g1.globo.com/go/goias/noticia/2019/05/31/ sera-que-nao-esta-na-hora-de-termos-um-ministro-no-supremo-tribunal-federal-evangelico-diz-bolsonaro-em-evento-religioso.ghtml. Acesso em 30/04/2021.

\section{Referências:}

AGUIÃO, Silvia. 2017. "Quais políticas, quais sujeitos? Sentidos da promoção da igualdade de gênero e raça no Brasil (2003-2015).” Cadernos Pagu, 51(1):75107.

ALMEIDA, Ronaldo de. 2019. "Bolsonaro presidente: conservadorismo, evangelismo e a crise brasileira.” Novos Estudos Cebrap, 38(1):185-213.

CAMURÇA, Marcelo. 2017. "A questão da laicidade no Brasil: mosaico de configurações e arena de controvérsias." Horizonte: revista de estudos de teologia e ciências da religião, 15(47):855-886.

CAMPOS, R., GUSMÃO, E. \& MAURICIO JUNIOR, C. 2015. "A disputa da laicidade: uma análise das interações entre Jean Wyllys e Silas Malafaia.” Religião e Sociedade, 35(2):165-188́.

CASANOVA, José. 1992. "Private and public religions." Social Research, 59(1):16-56.

. 2010. "A globalização do catolicismo e o retorno à uma igreja universal." Rever:Revista de Estudos da Religião, 10:17-45.

CARRARA, Sérgio. 2015. "Moralidades, racionalidades e políticas sexuais no Brasil contemporâneo.” Mana, 21(2):323-345.

CARRARA, S., FRANÇA, I. \& SIMÕES, J. 2018. "Conhecimento e práticas científicas na esfera pública: antropologia, gênero e sexualidade." Revista de Antropologia, 61(1):71-82.

CESARINO, Letícia. 2007. "Nas fronteiras do 'humano': os debates britânico e brasileiro sobre as pesquisas com embriões." Mana, 13(2):347-380.

COACCI, Thiago. 2020. "A queima dos laudos: controvérsias e reconfigurações dos saberes e direitos trans na ADI 4275.” Direito Eु Práxis, 11(2):1188-1210.

CORREA, Sonia. 2018. “A 'política do gênero’: um comentário genealógico.” Cadernos Pagu, 53(1):85-101.

DINIZ, Debora. 2014. "A arquitetura de uma ação em três atos: anencefalia no STF." UNB: Revista de Direito da Universidade de Brasília, 1(2):161-183.

DINIZ, D., MEDEIROS, M. \& MADEIRO, A. 2017. "Pesquisa nacional de aborto 2016." Ciência e Saúde Coletiva, 22(2):653-660.

EFREM FILHO, Roberto. 2019. “Os evangélicos como nossos 'outros': sobre religião, direitos e democracia.” Religião e Sociedade, 39(3):124-151. 
EFREM FILHO, Roberto. 2014. "Os ciúmes do direito: o desejo pelas uniões homoafetivas e a repulsa a Amor Divino e Paixão Luz.” Sexualidad, Salud y Sociedad: revista latinoamericana, 16:10-30.

FRASER, Nancy. 1995. "What's Critical about Critical Theory? The Case of Habermas and Gender." In MEEHAN, J. (ed.): Feminists read Habermas: Gendering the Subject of Discourse, 21-26. New York: Routledge.

FREIRE, Lucas. 2016. "Sujeitos de papel: sobre a materialização de pessoas transexuais e a regulação do acesso a direitos." Cadernos Pagu, 48(1):64-81.

FRY, P. \& CARRARA, S. 2016. "Se oriente, rapaz! Onde ficam os antropólogos em relação a pastores, geneticistas e tantos 'outros' na controvérsia sobre as causas da homossexualidade?". Revista de Antropologia, 59(1):258-280.

GOMES, Edilaine. 2009. "Fé racional e abundância: família e aborto a partir da ótica da Igreja Universal do Reino de Deus.” Sexualidad, Salud y Sociedad: revista latinoamericana, 2:97-120.

GONÇALVES, Alexandre. 2019. "Religião, política e direitos sexuais: controvérsias públicas em torno da 'cura gay”. Religião \& Sociedade, 39 (2):175-199.

HABERMAS, Jurgen. 2006. Entre naturalismo y religión. Barcelona: Paidós.

HARAWAY, Donna. 1995. "Saberes localizados: a questão da ciência para o feminismo e o privilégio da perspectiva parcial." Cadernos Pagu, 5:7-41.

LEITE, Vanessa. 2019. "Em defesa das crianças e da família: refletindo sobre discursos acionados por atores religiosos 'conservadores' em controvérsias públicas envolvendo gênero e sexualidade." Sexualidad, Salud y Sociedad: revista latino-americana, 32:119-142.

LUNA, Naara. 2018. "O julgamento no Supremo do aborto anencefálico - ADPF 54: uma etnografia da religião no espaço público." Horizontes Antropológicos, 24(52):165-197.

. 2013. "O direito à via no contexto do aborto e da pesquisa com célulastronco embrionárias: disputas de agentes e valores religiosos em um estado laico.” Religião $\mathcal{E}$ Sociedade, 33(1):71-97.

MACHADO, Lia Zanotta. 2017. "O aborto como direito e o aborto como crime: o retrocesso neoconservador." Cadernos Pagu, 50(1):75-94.

MACHADO, L., MOTTA, A. \& FACCHINI, R. 2018. "Quem tem medo dos antropólogos? Dilemas e desafios para a produção e práticas científicas Apresentação." Revista de Antropologia. 61(1):09-32.

MACHADO, Bernardo Fonseca. 2019. "Moral do controle: sobre inquietações e propostas para pensar 'ideologia de gênero' e o Escola Sem Partido." Ćadernos de Campo, 28(2):32-38.

MACHADO, Maria D. 2018. "O discurso cristão sobre a 'ideologia de gênero'." Revista Estudos Feministas, 26 (2):47-63.

2000. "O tema do aborto na mídia pentecostal." Revista Estudos Feministas, 8:200-211. 
MARIANO, Ricardo. 2011. "Laicidade à brasileira: católicos, pentecostais e laicos em disputa na esfera pública." Civitas, 11(2):238-258.

MIGUEL, L. F., BIROLI, F. \& MARIANO, R. 2017. "O direito ao aborto no debate legislativo brasileiro: a ofensiva conservadora na Câmara dos Deputados." Opinião Pública, 23 (1):230-260.

MONTERO, Paula. 2006. "Religião, pluralismo e esfera pública no Brasil.” Novos Estudos Cebrap, 74:47-74. 2009a. "Secularização e espaço público: a reinvenção do pluralismo religioso no Brasil.” Etnográfica, 13(1):7-16. . 2009b. "Jürgen Habermas: religião, diversidade cultural e publicidade." Novos Estudos CEBRAP, 84:199-213.

. 2012. "Controvérsias religiosas e esfera pública: repensando o religioso como discurso." Religião e Sociedade, 32 (1):167-183.

OLIVEIRA, Alcilene. 2009. "O movimento Católicas pelo Direito de Decidir na América Latina: experiências em prol dos direitos sexuais e reprodutivos.” E-Cadernos CES, 4:157-176.

PISCITELLI, Adriana. 2017. "\#queroviajarsozinhasemmedo: novos registros das articulações entre gênero, sexualidade e violência no Brasil.” Cadernos Pagu, 50(1):75ُ-98.

RAQUENTAT JÚNIOR, Cesar A. 2011. "Ciência e religião: os debates em torno das pesquisas com células-tronco embrionárias no Brasil.” Ciências Sociais e Religião, 12(13):37-56.

ROSADO-NUNES, Maria J. 2012. "O tema do aborto na Igreja Católica: divergências silenciadas." Ciência Ë Cultura, 64(2):23-31.

RUIBAL, Alba M. 2020. "A controvérsia constitucional do aborto no Brasil: inovação na interação entre movimento social e Supremo Tribunal Federal.” Direito E̊ Práxis, 11(2):1166-1187.

SAID, Edward W. 2007. Orientalismo: o oriente como invenção do ocidente. São Paulo: Companhia das Letras.

SALES, Lilian. 2014. "A controvérsia em torno da liberação das pesquisas com células tronco embrionárias no Brasil: posições e argumentos dos representantes da Igreja Católica.” Revista de Antropologia, 57(1):179-214.

. 2015. "Em defesa da vida humana: moralidades em disputa em duas audiências no STF." Religião e Sociedade, 35(2):143-164.

SERRA, Cris. 2019. Viemos para comungar: os grupos católicos LGBTI brasileiros e suas estratégias de permanência na Igreja. Rio de Janeiro: Editora Metanoia.

VAGGIONE, Juan M. 2012. “La 'cultura de la vida': desplazamientos estratégicos del activismo católico conservador frente a los derechos sexuales y reproductivos." Religião e Sociedade, 32(2):57-80.

VIEIRA, A. \& EFREM FILHO, R. 2020. "O rei está nu: gênero e sexualidade nas práticas e decisões no STF.” Direito e Práxis, 11(2):1084-1136. 
The Pursued Majority: Religion, science and democracy in the public hearing on abortion in the Supreme Federal Court

Abstract: This article aims to contribute to the understanding of the
current religion configurations in the public controversy over the abortion
decriminalization in Brazil. To this end, we turn to the analysis of the public
hearing held at the Supreme Federal Court as part of the processing of ADPF
442 , but above all to the 24 exhibitions held by representatives of self-styled
religious entities and by the other exhibitors who cited religion for the
construction of their arguments contrary to or in favor of decriminalizing
abortion until the 12 th week of pregnancy. Such exhibitions give rise to
intense disputes - within a language of rights - over scientific knowledge,
different conceptions of democracy and religion itself. In these disputes,
religious actors often identify themselves as a majority persecuted for the
'ideological excesses' characteristic of a 'judicial activism' led by the STF
ministers and contrary to what would be the 'moral of the people' in Brazil.

Keywords: Abortion, Religion, Science, Democracy, STF.

Recebido em junho de 2021.

Aprovado em outubro de 2021. 